\title{
עידן יצירת המיתוסים: מיתוס טרומפלדור ומיתוס ברנר
}

"יהודה עכשיו, יהודה תמיד, משא דווי ומשא גיל״, ובו השורות על הצעירים שעולים לגרדום, ושחר ירושלים בשעוות פניהם, שיר שנכתב שנים לפני שצעירים יהודים נידונו לעלות לגרדום, מבשר את העתיד או אולי אף מעצב אותו. ועוד תכונה יש למיתוסים, שנסיבות האירוע שסביבו נארגו יש בהן משהו מסתורי, לא מפוענח עד הסוף. ככל

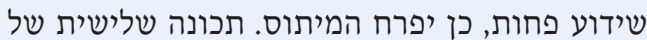
המיתוסים היא שהם מטפחים ומבליטים את הקורבן ומתעלמים מן התוקפן, הרוצח, עד כדי טשטושו.

\section{מיתוס טרומפלדור}

מה שקרה בתל חי היה מוות צפוי מראש: הגליל העליון היה שטח הפקר בין צבאות לוחמים, בין הצרפתים לבין צבאו של האמיר פייסל, שהבריטים הבטיחו לו את השלטון בדמשק אם יכריז מרד

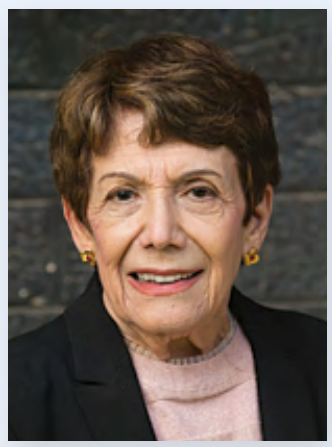

כמעט באותו הזמן - המיתוס של של טרומפליג מיתורי, שנוצרו ותל חי והמיתוס של רצח ברנר.

מהו מיתוס? בדרך כלל זהו סיפור על אירוע או אדם שבמשך הזמן נוצרת סביבו הילה שהולכת וגדלה ומקבלת משמעות מעבר לכאן ועכשיו. כאשר זה קורה, עלינו לשאול את עצמנו למה דווקא אירוע או אדם זה הפך לגרעין המיתוס, ומה היה באותה תקופה ובאותה סיטואציה שהזמין את היווצרות המיתוס. כן נשאלת השאלה מי היו מטפחי המיתוס, ומה היה אורך חייו. - (סיון.

למיתוסים יש תכונה להיראות בדיעבד כאילו האירוע שסביבו נארגו היה צפוי מראש, כמו האקדח במערכה הראשונה שיורה במערכה השלישית. אני תמיד מצטמררת כשאני קוראת את שירו של אצ"ג, 


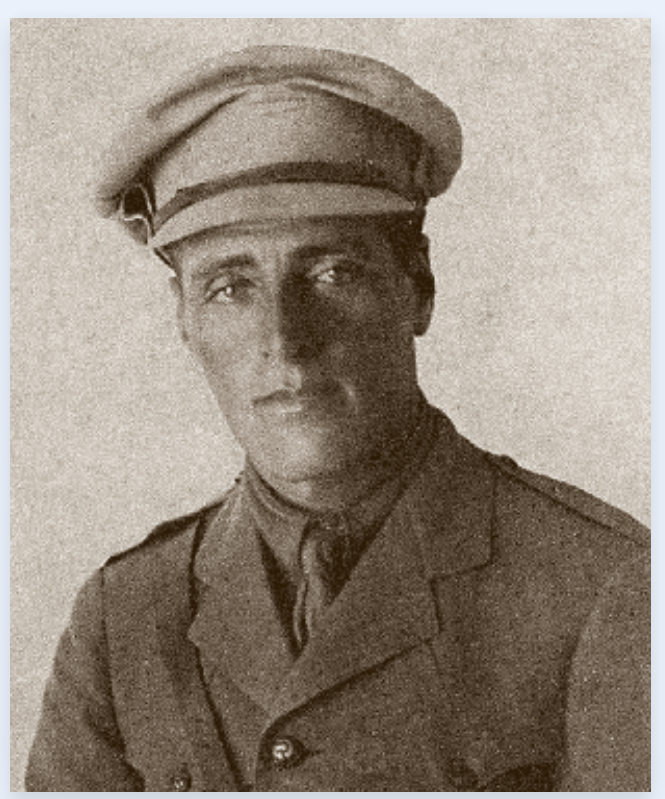

איור 1. יוסף טרומפלדור (1920-1880)

סיוון תרע"ט)]. במאמר שמוכתר בכותרת "בימים חמורים אלה" דורש ה"קונטרס" "לחזק הישובים

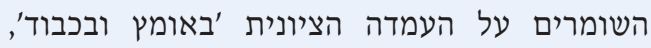
שעומדים 'על משמר הכבוד', והמערכת שולחת הכמדים

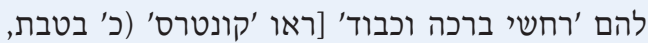

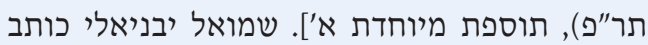

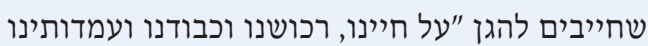
הלאומיים" בצפון [ראו שמואל יבניאלי, "בצור

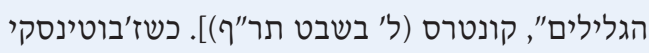

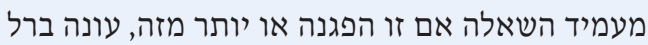

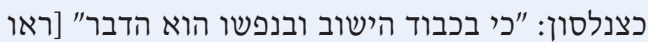

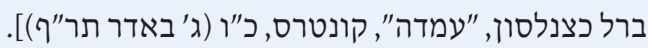

אחת היצירות של ברנר, שנקראה בקרב תנועות הנוער והייתה פופולרית בהרבה מהרומנים המורכבים והקשים לקריאה שלו, היה הסיפור

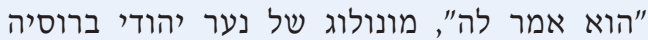

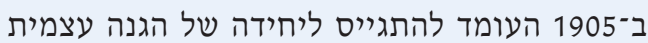
ומנהל ויכוח עם אימו, שמביאה להצדקתה את כליס ליחידה של הגנה עצמית הנימוקים של אז"ר, ועוד טובים מאלה בהרבה, 4

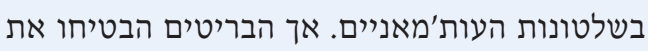
סוריה גם לצרפתים בהסכם סייקס-פיקו ונסוגו

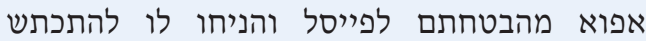

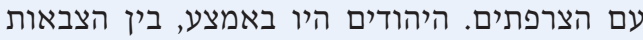

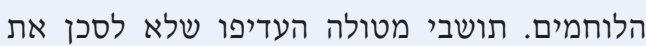

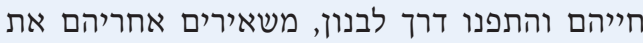

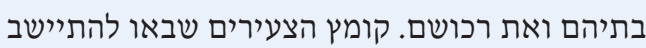

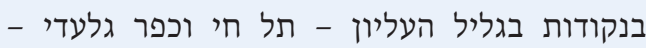

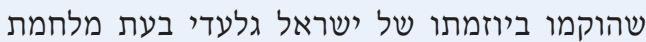

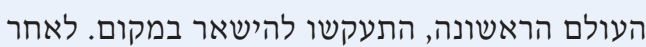

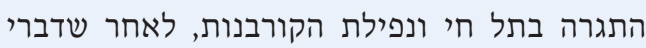

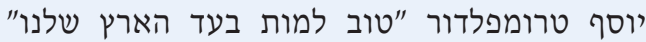
נפוצו כאש בכל הארץ, התגלה במערכת השבועון

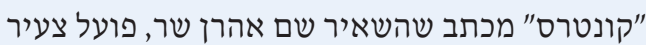

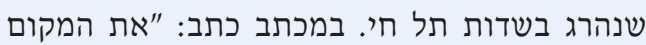

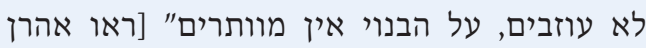
שר, "למשמר", קונטרס, כ' (י״ח בטבת תר"ף), עמ' אוזים

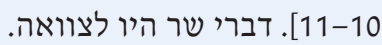

בדיונים בוועד הצירים ובוועד הזמני, קודם לנפילת

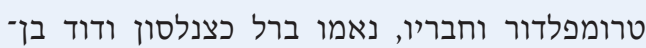

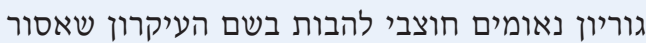

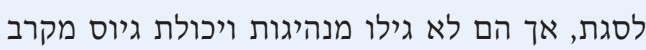

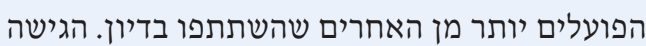
הרציונלית של ז'בוטינסקי, שדרש לסגת בינתיים עד שיתייצב המצב, והגישה האנושית של אז"ר, שטען

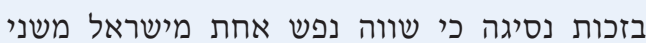

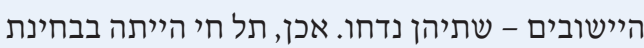

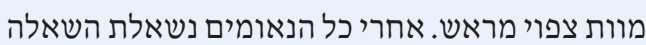

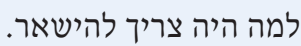

כשקוראים את דפי "קונטרס" מאותה תקופה, קל להבחין שהמילה שחוזרת כמעט בכל מאמר שנוגע מאים

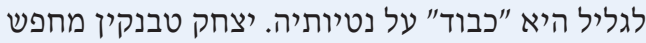

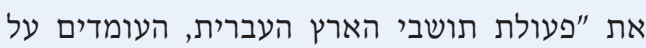

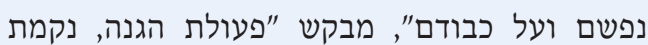

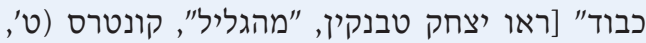


כל תנועה לאומית זקוקה לדמויות מופת אשר חייהן ומותן הם משל ודוגמה להתעלות שנדרשת לאומית לות למויות מופת אשר

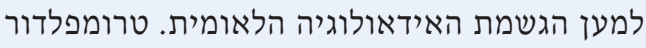

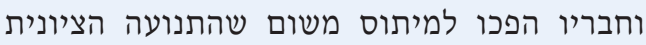

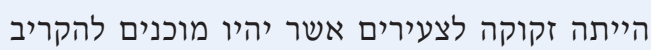

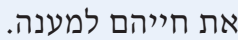

בימי העליות הראשונות הנושא הזה לא היה קריטי:

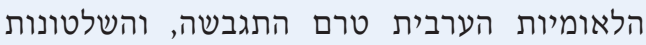

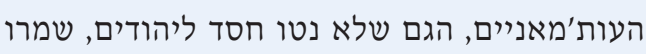

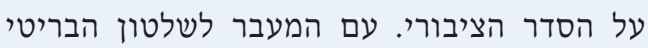

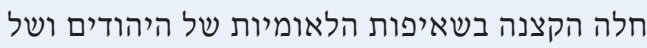

הערבים גם יחד.

היהודים בארץ סברו באותה עת שהקמת המדינה

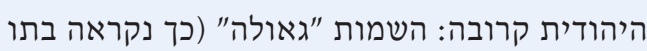

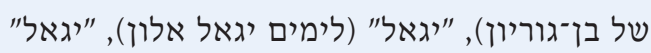

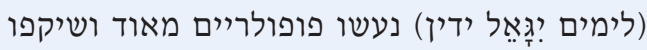
את תחושת היהודים שהגאולה ממשמשת ובאה. מנגד, ערביי ארץ ישראל מצאו עצמם מאבדים היהודים שמשמשת ובאה שמשה

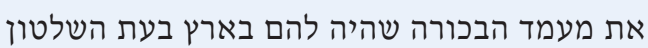
העות'מאני המוסלמי. הם ציפו להקמת מדינה הבכורה לה ביץ בעת הלטון

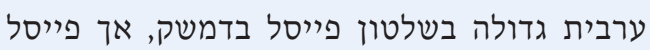

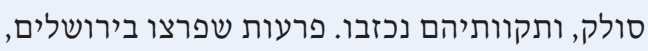
כחודש לאחר פרשת תל חי, התקבלו בקרב

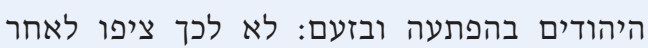

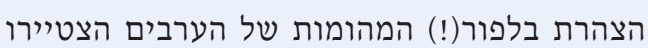
בעיניהם כמקבילה של הפוגרומים ברוסיה. היד הרכה יחסית של השלטונות הבריטיים ונטייתם

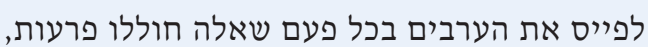

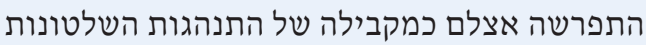

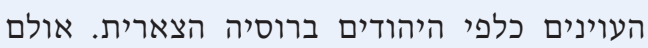

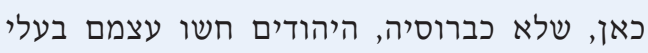

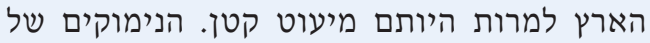

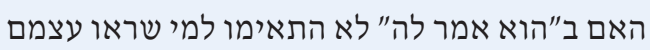

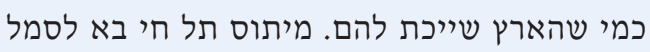

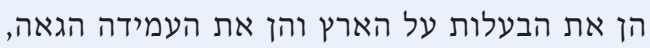

נגד ההתנגדות בכוח לפורעים: הם רבים ואנחנו

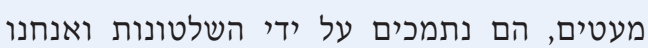

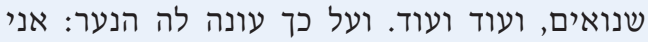

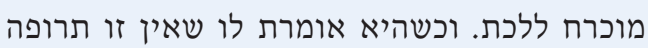

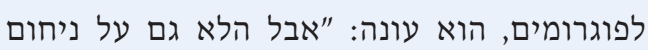

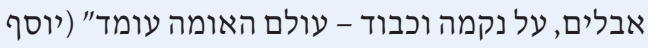
חיים ברנר, "הוא אמר לה", כתבים, כרך ראשון,

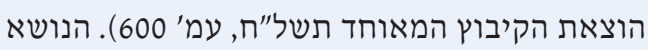
של הכבוד הלאומי בער בנפשם של בני התקופה. מדובר בדור שחווה השפלה, פרעות ואובדן.

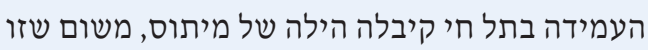

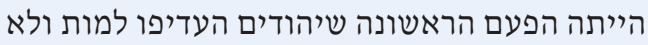

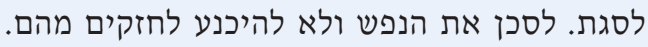

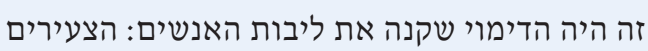

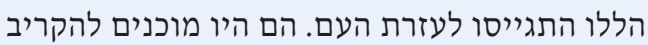

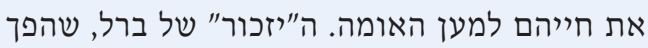

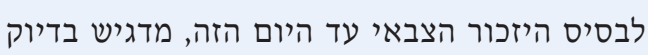

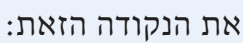

יזכור עם ישראל - [לא אלוהי ישראל] - את הנשמות הטהורות של בניו ובנותיו, הנאמנים

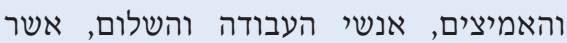

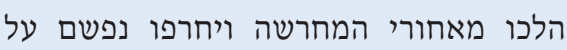

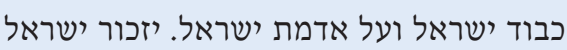

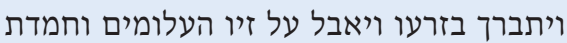

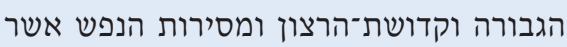

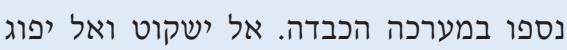

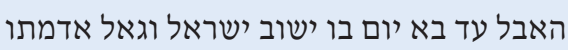

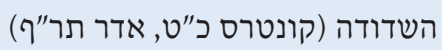

כבוד ישראל קודם לאדמת ישראל, מסירות הנפש

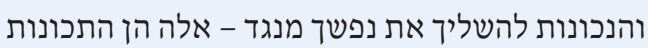
שיביאו את העתיד, ש"בו ישוב ישראל וגאל אדמתו

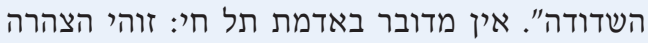

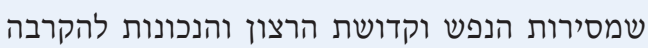

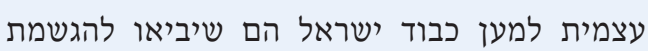

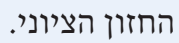




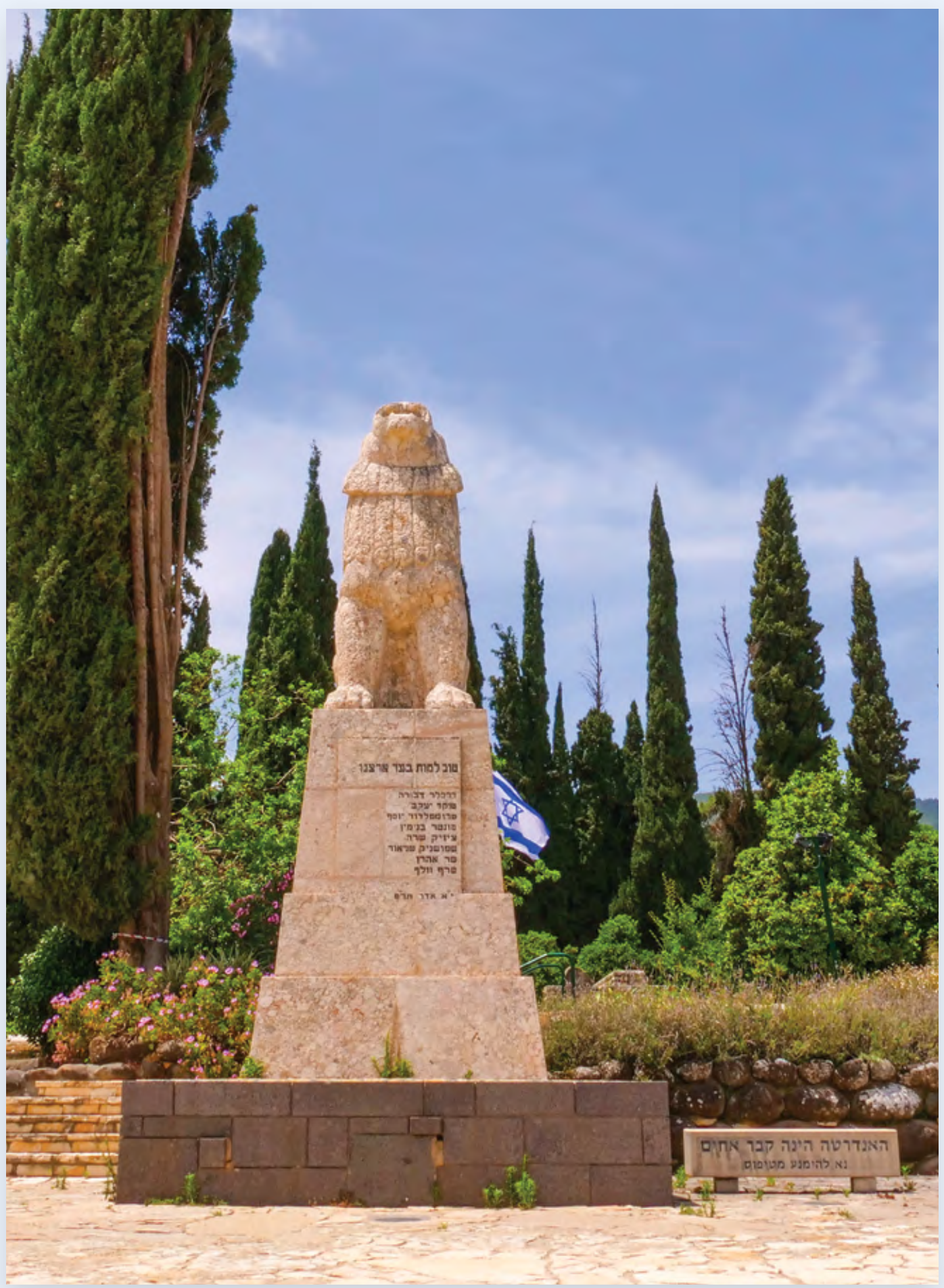


ז'בוטינסקי, שגרס שיש לפנות את היישובים, סייע

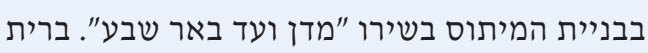
תרומפלדור, הלא היא תנועת בית"ר, השתמשה

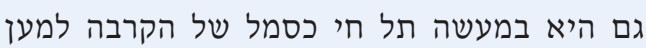

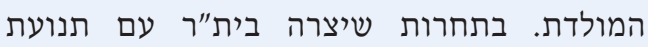
העבודה על הבעלות על זכרו של הגיבור הגידם

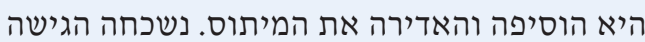

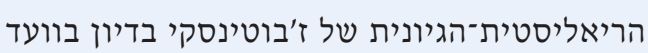

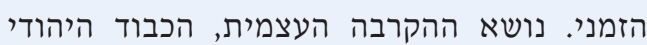

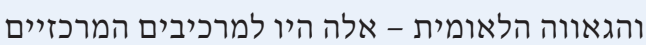
בחינוך של הנוער בארץ ישראל.

למיתוס נועדו חיים ארוכים: לאחר מלחמת ההתשה, ובייחוד לאחר מלחמת יום הכיפורים, נוכום לארים

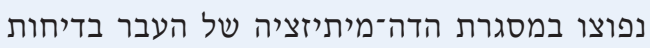

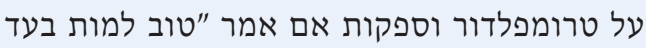
ארצנו" או שמא השמיע קללה ברוסית. תיאטרון הקאמרי הציג את "מלכת אמבטיה" של חנוך לוין

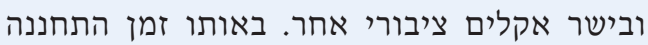
רעיה הרניק, אשת רדיו, לפני בנה גוניק: מסוכן

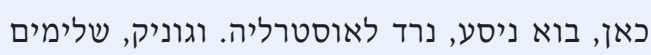

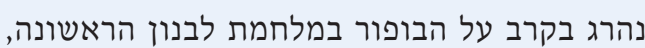

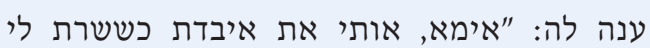
'בגליל בתל חי'".

\section{מיתוס ברנר}

ברנר נרצח למוחרת הפסח ב־1921, כשנה לאחר

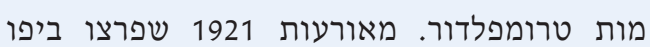
היו טראומטיים מאירועי תל חי, הן בשל מספר

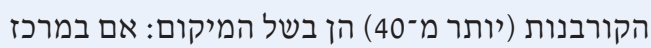

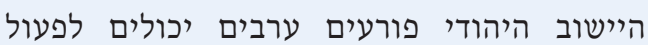

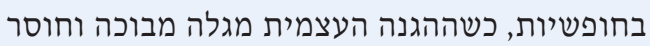
ישע, מה יגידו יישובי הספר? אך הטראומה נשכחה. מה שנשמר בזיכרון הלאומי מאותם ימים הספר היה הטראומה נשכחה. ברנר וחמשת חבריו.
השונה מעמידת היהודים בארץ לא להם. אולם

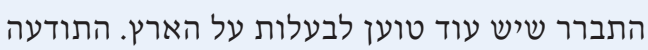

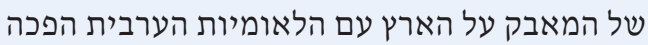
ב־1920 מלטנטית לפעילה.

המתיישב הציוני, גיבור העלייה השנייה, סבר, כמו

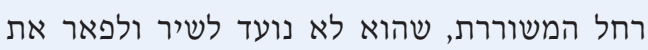

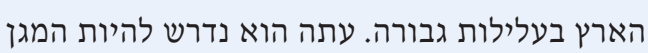

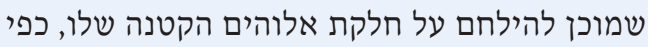
שעשה טרומפלדור: "כל היום אני חרשתי ובלילה קנה רובי ביד אחת אחזתי, עד הרגע האחרון". השירים "מדן ועד באר שבע", "כחזון תוחלת",

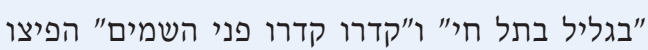

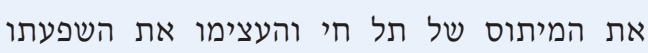

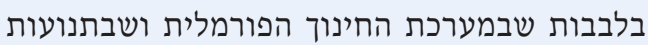

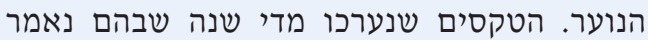

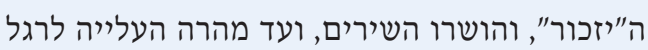

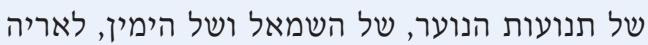

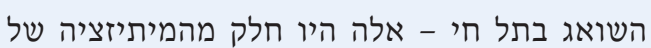

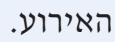

עם הזמן השתרשה בציבור הסברה שקיומם של

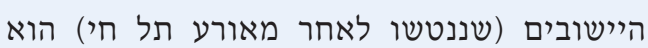
שהביא בסופו של דבר להכללת הגליל העליון

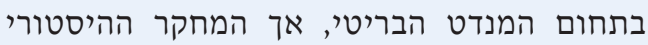

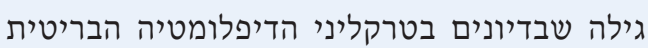

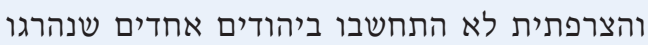

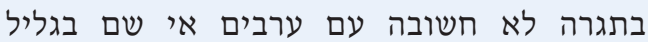
העליון. שיקולים אחרים קבעו את קו הגבול.

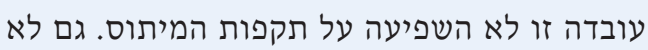

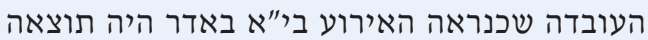

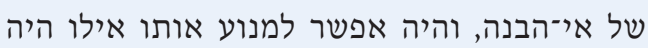

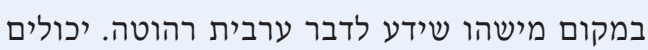
ההיסטוריונים "לרכל" כאוות נפשם על היחסיד לדבר ערבים רהום יכולים

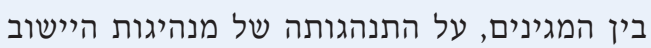

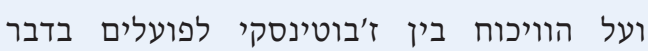
ההיגיון שבעמידה במקום; הרי בסופו של דבר גם 
בתוך כפר ערבי, מנותק מיישוב יהודי, מזה. אך

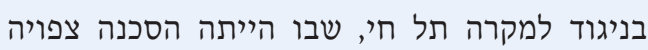

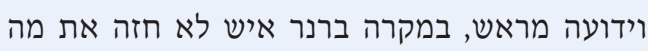

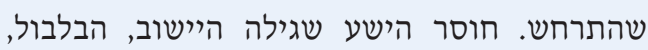

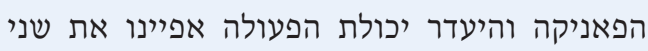

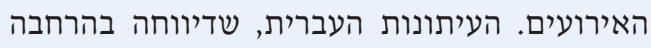

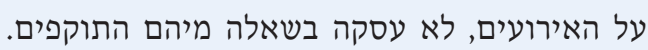

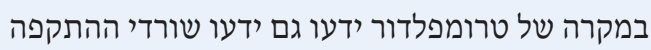

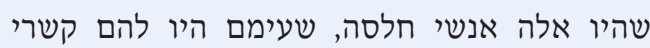
ידידות לפני התגרה וגם אחריה, אך העיתונות שלסה היות להם קשרי

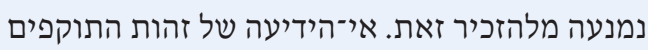

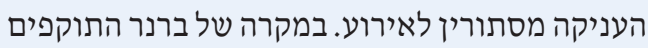

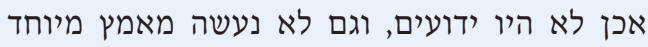

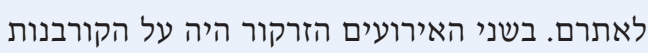

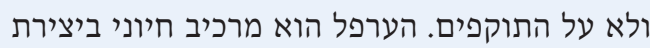

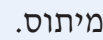

מותו של ברנר היה אפוף מסתורין. הסיבה שבשלה

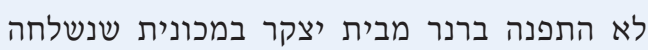

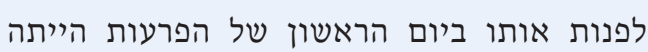
בגדר תעלומה. אומנם שני כוורנים מנס ציונה הלת הפרעת היותה שהתגלגלו לבית יצקר ונחפזו לנצל את המכונית שומני שורנים מנסיונה

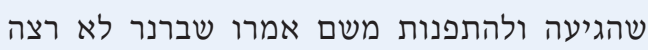

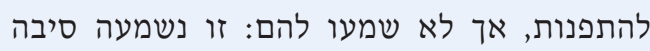

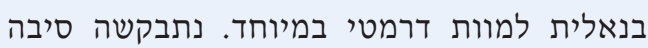
שתצביע על נכונות גיבור התרבות ברנר להקריב

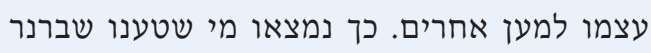

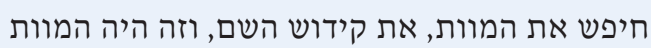

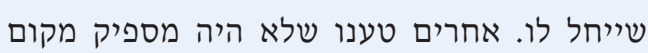

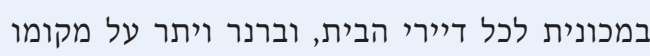

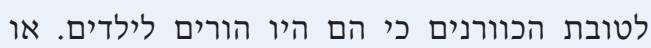

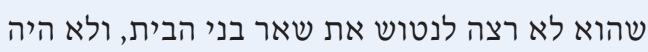

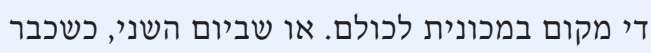

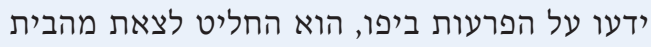
כדי לחלוק את גורלו עם גורל אחיו היהודים ביפו. ועוד טענו שהוא נמצא מת ואגרופו קמוץ, נכון 4

להיאבק עד הרגע האחרון.

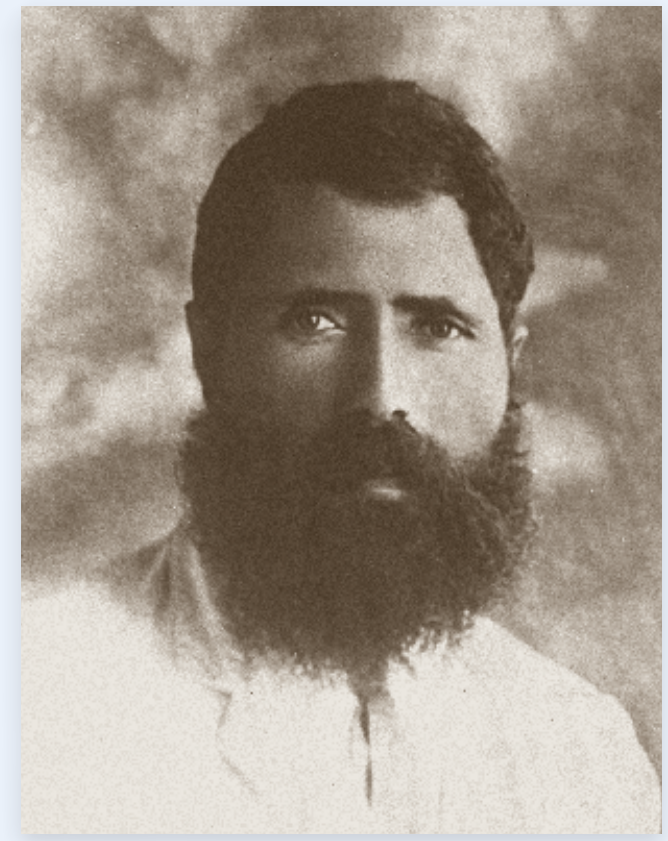

איור 3. יוסף חיים ברנר (1921-1881). התמונה באדיבות המכון לחקר תנועת העבודה ע"ש פנחס לבון

שלא כטרומפלדור, שלא גילה בחייו דאגה מפני

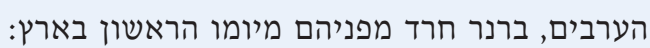

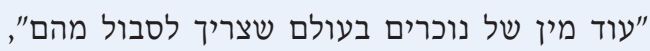

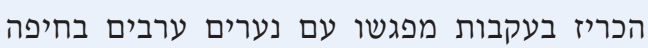
(ראו ברנר, "מכאן ומכאן", כתבים ב', עמ' 1324).

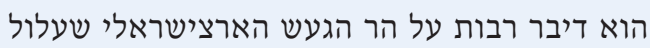

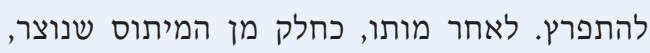

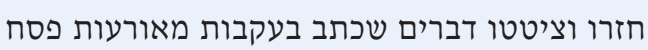
תר"ף, זמן קצר אחרי תל חי: "מחר אולי תידקר היד

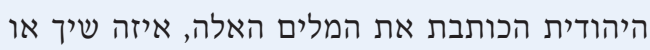

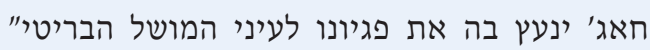

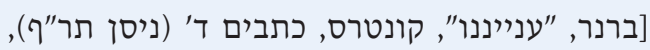

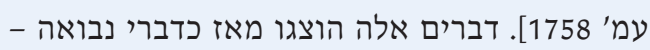
מוות ידוע מראש.

היו קווים מקבילים בין אירוע תל חי לרצח ברנר

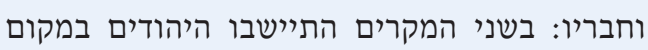
מועד לפורענות: הגליל העליון מזה, ובית ערבי, 


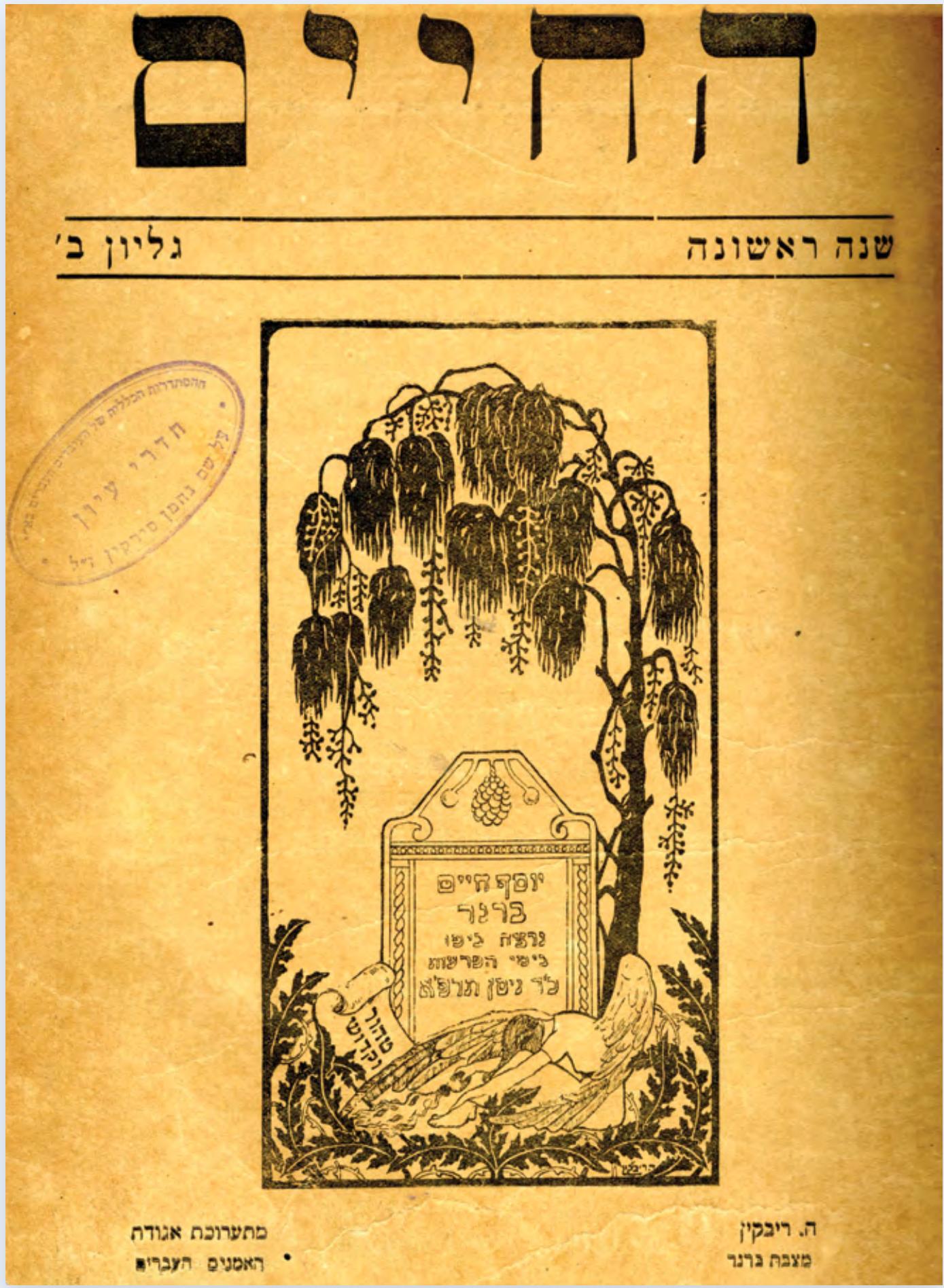

איור 4. מצבת זיכרון סמלית לחיים ברנר. צייך: ה. ריבקין (התמונה באדיבות המכון לחקר תנועת העבודה ע"ש פנחס לבון) 
הקדוש. הוא נקבר בקבר אחים בבית העלמין החדש

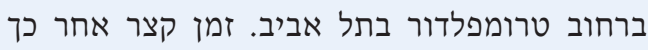
צייר אומן בשם ריבקין מצבה בסגנון אר דקו, ולידה מלאך שמשתחווה למצבה, וכתובת: "טהור וקדוש".

תנועה לאומית נבנית על דם קדושיה וגיבוריה,

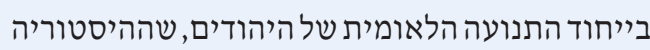

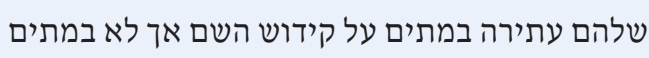

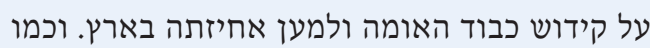

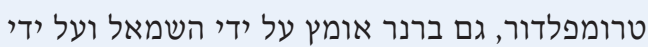

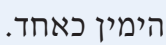

תנועות לאומיות אוהבות כישלונות מפוארים שמצביעים על הנכונות להקרבה למען הרעיון.

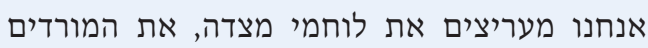

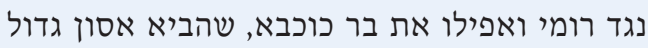

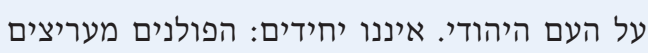

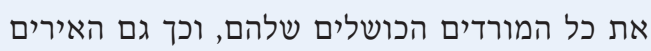
והיוונים, ויש לשער שגם עמורים הכושלים שלהם, וכך אחרים האירים שידעו

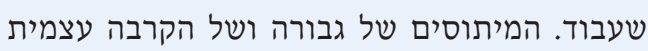
יש להם כוח וחיוניות ששמים לאל את ניסיוניתות ושל הקרבה עצמית הרציונליסטים למיניהם ולדורותיהם לקעקע אותם. וגם ההיסטוריונים אינם מצליחים בכך. המיתוסים למינים ליתים חזקים מאיתנו, ואולי כך ראוי.
כל ההסברים המתוחכמים הללו על מות ברנר נבעו

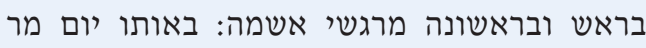
ונמהר, כשהפאניקה ואובדן העשתונות שררו ביפו

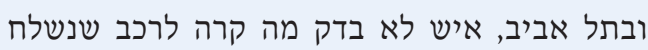

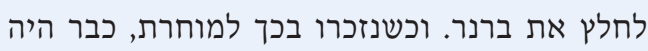

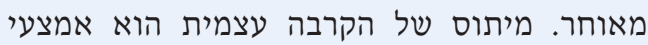
מצוין לחיפוי על רגשות אשם. מאוס שקרבה

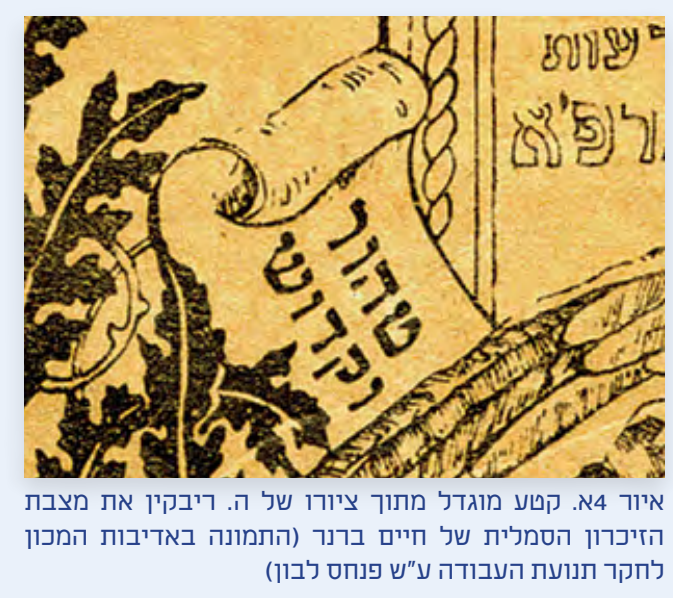

מוות מפואר הוא מוות ראוי, שאפשר לחנך עליו.

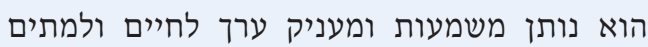

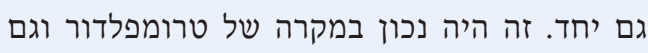

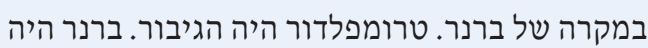

